\title{
Vulnerability of the Human Airway Epithelium to Hyperoxia Constitutive Expression of the Catalase Gene in Human Bronchial Epithelial Cells Despite Oxidant Stress
}

\author{
Jee-Hong Yoo, Serpil C. Erzurum, John G. Hay, Patricia Lemarchand, and Ronald G. Crystal \\ Pulmonary Branch, National Heart, Lung, and Blood Institute, National Institutes of Health, Bethesda, Maryland 20892
}

\begin{abstract}
Although catalase is a major intracellular antioxidant, the expression of the human catalase gene appears to be limited in the airway epithelium, making these cells vulnerable to oxidant stress. The basis for this limited gene expression was examined by evaluation of the expression of the endogenous gene in human bronchial epithelial cells in response to hyperoxia. Hyperoxia failed to upregulate endogenous catalase gene expression, in contrast to a marked increase in expression of the heat shock protein gene. Sequence analysis of $1.7 \mathrm{~kb}$ of the 5 '-flanking region of the human catalase gene showed features of a "housekeeping" gene (no TATA box, high GC content, multiple CCAAT boxes, and transcription start sites). Transfection of human bronchial epithelial cells with fusion genes composed of various lengths of the catalase 5'-flanking region and luciferase as a reporter gene showed low level constitutive promoter activity that did not change after exposure to hyperoxia. Importantly, using a replication-deficient recombinant adenoviral vector containing the human catalase cDNA, levels of catalase were significantly increased in human airway epithelial cells and this was associated with increased survival of the cells when exposed to hyperoxia. These observations provide a basis for understanding the sensitivity of the human airway epithelium to oxidant stress and a strategy for protecting the epithelium from such injury. (J. Clin. Invest. 1994.93:297-302.) Key words: catalase - gene expression - hyperoxia • adenovirus • gene transfer
\end{abstract}

\section{Introduction}

The human airway epithelium, a surface of 1-2 $\mathrm{m}^{2}$, has the potential of exposure to a variety of oxidants, including hyperoxia, air-borne pollutants, cigarette smoke, and products of inflammation (1-4). Like other cells, airway epithelial cells rely on antioxidant enzymes for protection against oxidant stress, including superoxide dismutase, catalase, and the glutathione system ( 5-7). Catalase, a 240-kD tetrameric heme protein, plays a central role in this protective screen by virtue of its ability to convert hydrogen peroxide $\left(\mathrm{H}_{2} \mathrm{O}_{2}\right)$ to oxygen and water (8). If the amounts of catalase are insufficient to handle the intracellular burden of $\mathrm{H}_{2} \mathrm{O}_{2}$ and other anti- $\mathrm{H}_{2} \mathrm{O}_{2}$ protective mechanisms do not compensate, $\mathrm{H}_{2} \mathrm{O}_{2}$ and its toxic derivatives are free to damage a variety of vulnerable biologic processes, eventually causing cell death $(5-7,9)$.

Address correspondence and reprint requests to Ronald G. Crystal, Room 6D03, Building 10, National Heart, Lung, and Blood Institute, National Institutes of Health, Bethesda, MD 20892.

Received for publication 24 March 1993 and in revised form $2 \mathrm{Au}$ gust 1993.

The Journal of Clinical Investigation, Inc.

Volume 93, January 1994, 297-302
Although the function of catalase suggests that it must be vital for the survival of the airway epithelium, it appears that the human airway epithelium has limited amounts of catalase, and does not increase the expression of catalase in response to oxidant stress. In this regard, the levels of catalase mRNA in the human airway epithelium are very low, only 1-2 copies/ cell (10). Further, when normal humans inhale $100 \% \mathrm{O}_{2}$ for $>12 \mathrm{~h}$, the mRNA levels of catalase in the airway epithelium do not change, while most individuals develop early evidence of tracheobronchitis (10).

In the context of these observations, the present study is directed toward evaluation of the regulation of catalase gene expression in human airway epithelial cells in vitro. The data demonstrate that expression of the human catalase gene is not upregulated in human airway epithelial cells in response to hyperoxia, the 5'-flanking region of the human catalase gene has characteristics of a nonregulated "housekeeping" gene and does not respond to a hyperoxic stimulus. However, when human airway epithelial cells are infected with an adenoviral vector containing the human catalase cDNA, the level of catalase activity increases as does the survival of the cells in a hyperoxic environment. Together, the data support the concept that the expression of human catalase gene is insensitive to oxidant stress in human airway epithelial cells, limiting the potential of this important antioxidant in protecting the airway. However, if the catalase levels in the cells can be increased, such as by transfer of the catalase cDNA to the cells, catalase can function to protect airway epithelial cells from hyperoxia.

\section{Methods}

Cell cultures. BET-1A cells (gift of J. E. Lechner, National Cancer Institute, Bethesda, MD), a human bronchial epithelial cell line transformed by the SV40 virus, were cultured in serum-free LHC- 9 medium with $25 \mu \mathrm{g} / \mathrm{ml}$ fungizone, $25 \mathrm{U} / \mathrm{ml}$ penicillin, and $25 \mu \mathrm{g} / \mathrm{ml}$ streptomycin (all from Biofluid Inc., Rockville, MD) (11). HS-24 cells, a human bronchial carcinoma cell line (provided by W. Ebert, Thoraxklinikum, Heidelberg-Rohrbach, Germany) were cultured in RPMI 1640 with $25 \mathrm{mM}$ Hepes, pH 7.4, $2 \mathrm{mM}$ glutamine, $100 \mu \mathrm{g} / \mathrm{ml}$ gentamicin (all from GIBCO BRL, Gaithersburg, MD), and 10\% fetal bovine serum (Biofluid Inc.) (12).

To evaluate the response of the catalase gene to hyperoxia, the cells were grown to $95 \%$ confluence in $21 \% \mathrm{O}_{2}$, and then moved to a humidified hyperoxic chamber (controlled atmosphere culture chamber; Bellco Biotechnology, Vineland, NJ) contained within a water-jacketed incubator (Forma Scientific, Marietta, $\mathrm{OH}$ ) flushed with $95 \% \mathrm{O}_{2}$ / $5 \% \mathrm{CO}_{2}$ mixed gas at a flow rate to maintain a concentration of $85 \%$ $\mathrm{O}_{2}$. Temperature and the percentage of $\mathrm{O}_{2}$ in the chamber were monitored throughout the study (model 600 oxygen analyzer; Engineered Systems and Designs, Newark, DE). Control cells and cells exposed to hyperoxia were harvested for analysis after 24 or $48 \mathrm{~h}$.

$R N A$ extraction and analysis. Total cellular RNA was isolated from cells under normoxia and hyperoxia by the guanidinium thiocyanatecesium chloride gradient method and evaluated by Northern analysis (13). RNA ( $10 \mu \mathrm{g})$ was subjected to formaldehyde-agarose gel electro- 
phoresis and transferred to a nylon membrane (Duralon-UV; Stratagene Inc., La Jolla, CA). All of the RNA samples from each cell line in both normoxic and hyperoxic conditions were analyzed on the same blot and sequentially hybridized with the different probes. Catalase mRNA transcripts were evaluated by hybridization of the membrane with $\mathrm{a}^{32} \mathrm{P}$-labeled human catalase cDNA probe. Controls included evaluation of $18 \mathrm{~S}$ ribosomal RNA (RNR-18S) ${ }^{1}$ as a negative control, and of heat shock protein-70 (HSP-70) mRNA as a positive control of oxidant stress $(14,15)$. Transcripts were quantified by use of a phosphorimager (Molecular Dynamics, Sunnyvale, CA). The human catalase cDNA ( $\lambda$ hCAT-2) was provided by $R$. Hallewell (Chiron Corp., Emeryville, CA). The cDNA clone pH2.3 (ATCC 57495; American Type Culture Collection, Rockville, MD) was used for the HSP-70 probe, and the cDNA clone HHCSA65 (ATCC 77242) was used for the RNR-18S probe.

Catalase activity. Catalase activity was determined in the cell lines under conditions of normoxia $\left(21 \% \mathrm{O}_{2}\right)$ and hyperoxia $\left(85 \% \mathrm{O}_{2}, 48\right.$ h). The cells were lysed in lysis buffer ( $10 \mathrm{mM}$ ethylenediaminetetraacetic acid, $2 \%$ Triton $\mathrm{X}$, and $\mathbf{0 . 0 5 \%}$ deoxycholic acid, in phosphate buffered saline, $\mathrm{pH}$ 7.4). Catalase activity was quantified by the method of Aebi (16), in which $\mathrm{H}_{2} \mathrm{O}_{2}$ is reacted with the cell lysates. The initial rate of disappearance of $\mathrm{H}_{2} \mathrm{O}_{2}(0-30 \mathrm{~s})$ is measured spectrophotometrically at a wavelength of $240 \mathrm{~nm} ; 1 \mathrm{U}$ of catalase activity is defined as the rate constant of the first order reaction using purified human erythrocyte catalase as a standard. Activity units for catalase were expressed as milliunits relative to total cell lysate protein (BCA protein assay reagent, Pierce Chemical Co., Rockford, IL).

Characterization of the 5'-flanking region of the human catalase gene. A 3.1-kb EcoRI DNA fragment containing $1.7 \mathrm{~kb} 5$ '-flanking region, exon 1 , and $1.3 \mathrm{~kb}$ of intron 1 was isolated from a human chromosome 11-specific library (ATCC 57726), subcloned into pBluescript II SK + (pPB390), and sequenced by the dideoxy chain termination method (17). The sequence of $1.7 \mathrm{~kb}$ of the 5 '-flanking region of the human catalase gene was compared with the 4.8-kb 5'flanking region of the rat catalase gene using DNASIS Homology Search program (HIBIO DNASIS; Hitachi Software Engineering America, Brisbane, CA). Transcriptional regulatory elements in the human 5 '-flanking sequences were identified from the transcription factors database (18) using sequence analysis software (version 7.0 Genetics Computer Group, Madison, WI) (19).

To identify the transcription start sites for the human catalase gene, primer extension analysis was performed using two different $\left[\gamma^{32} \mathrm{P}\right]-$ ATP ( $>5000 \mathrm{Ci} / \mathrm{mmol}$; Amersham Corp., Arlington Heights, IL) end-labeled antisense primers located in exon 1 (CAT-21 [5'-GCTGCTCCTTCCAGTGCTGCATCT-3'] and CAT-24 [5'-TGTGCAGAACACTGCAGGAGGC-3']). Briefly, $100 \mu \mathrm{g}$ of total RNA was hybridized with $5 \times 10^{5} \mathrm{dpm}$ of CAT-21 and CAT-24, and incubated with Moloney murine leukemia virus reverse transcriptase (GIBCO BRL) and unlabeled nucleotide triphosphates. Primer extension products were then fractionated on denaturing polyacrylamide gels and evaluated by autoradiography (20).

S1 nuclease mapping for transcription start sites was performed using a 317-bp end-labeled single stranded probe. $100 \mu \mathrm{g}$ of RNA extracted from BET-1A cells was hybridized with the probe and digested with S1 nuclease following standard methods (21).

Evaluation of promoter activity of catalase gene 5'-flanking sequences. Transfection vectors containing fusion genes of catalase gene 5 '-flanking sequences and a luciferase reporter gene were constructed from a pUC8-derived vector (pCMV-luciferase) (22). Sequentially de-

1. Abbreviations used in this paper: AdCL, a replication-deficient Ad5based virus containing the human catalase CDNA; AdCFTR, an Ela ${ }^{-}$ partial $\mathrm{Elb}^{-}, \mathrm{El}^{-}$, replication-deficient Ad5-based adenovirus containing human cystic fibrosis conductance regulator cDNA; CAT, chloramphenicol acetyltransferase; HSP-70, heat shock protein-70; MTT, 3-(4,5-dimethylthiazol-2-yl)2,5-diphenyl tetrazolium bromide; RNR-18S, ribosomal 18S RNA. leted fragments of the catalase gene 5'-flanking region were prepared by polymerase chain reaction amplification with pPB390 as a template and substituted for the cytomegalovirus promoter in the pCMV-luciferase expression vector (21). The Rous sarcoma virus-long terminal repeat promoter-luciferase construct ( $\mathrm{pRSVLuc}$ ) was used as a positive control (23), and a promoterless luciferase plasmid as a negative control. HS-24 cells were cotransfected using $N$-[1-(2,3-dioleoyloxyl) propyl]- $N, N, N$-trimethylammoniummethylsulfate (transfection reagent Boehringer Mannheim Corp., Indianapolis, IN) with $5 \mu \mathrm{g}$ of each luciferase expression plasmid vector and $2 \mu \mathrm{g}$ of a cytomegalovirus promoter-chloramphenicol acetyltransferase (CAT) expression plasmid as an internal control (22). Cells were evaluated for luciferase activity after $48 \mathrm{~h}$ (23). To evaluate luciferase activity in the context of exposure to hyperoxia, the cells were moved to an $85 \%$ oxygen chamber $24 \mathrm{~h}$ after transfection and incubated for a further $24 \mathrm{~h}$. CAT activity was assayed with a two-phase fluor-diffusion assay (24). Levels of luciferase expression by the various vectors were normalized by CAT activity and shown relative to the expression of pRSVLuc (defined as 100\%).

Augmentation of catalase activity. In the context that the catalase gene is not upregulated by hyperoxia, it is rational to ask whether airway epithelial cells could be protected from hyperoxia if catalase amounts could be increased in the cell. To evaluate this, we used the recombinant adenovirus $\mathrm{AdCL}$, an $\mathrm{Ela}^{-}, \mathrm{E}^{-}$, replication-deficient Ad5-based adenovirus containing the human catalase cDNA (25), to transfer the catalase cDNA to the cells and to increase the production of intracellular catalase.

After HS-24 cells were grown to $60-70 \%$ confluence, they were infected with AdCL or as a negative control, AdCFTR ( an Ela ${ }^{-}$, partial $\mathrm{Elb}^{-}, \mathrm{E3}^{-}$, replication-deficient Ad5-based adenovirus containing the human cystic fibrosis transmembrane conductance regulator cDNA [26]) at 25 plaque-forming units/cell. As a further control, uninfected cells were evaluated in parallel. The cells were incubated for $30 \mathrm{~min}$ with medium-containing virus and $2 \%$ bovine calf serum, and then incubation was continued for $72 \mathrm{~h}$ after addition of medium with $10 \%$ bovine calf serum (27). To demonstrate that the AdCL vector transferred a functional catalase cDNA to the cells, catalase activity was measured in uninfected, AdCFTR-, or AdCL-infected HS-24 cells.

In parallel cultures, after $72 \mathrm{~h}$ of infection, cells were moved to a humidified hyperoxia chamber with $95 \% \mathrm{O}_{2}$ and incubated for $72 \mathrm{~h}$. The HS- 24 cells were exposed to $95 \% \mathrm{O}_{2}$ for this evaluation (instead of $85 \% \mathrm{O}_{2}$ used in previous experiments) after initial studies had shown that $95 \% \mathrm{O}_{2}$ placed a high oxidant stress on the cells with higher subsequent cell death. The viability of the cells was quantified by the 3-(4,5dimethylthiazol-2-yl )2,5-diphenyl tetrazolium bromide cleavage assay (28). The amount of MTT reduced to its blue formazan derivative by viable cells during an additional $4 \mathrm{~h}$ of culture was quantified spectrophotometrically at $540 \mathrm{~nm}$ using an ELISA reader (Bio Rad Laboratories, Melville, NY.); there is a linear relationship between the formazan generated and the number of viable cells present $(28)$. The fraction of cells surviving hyperoxic exposure was expressed as the ratio of the optical density at $540 \mathrm{~nm}\left(\mathrm{OD}_{540}\right)$ of cells incubated in $95 \% \mathrm{O}_{2}$ compared to the $\mathrm{OD}_{540}$ of cells incubated in $21 \% \mathrm{O}_{2}$.

\section{Results}

Effects of hyperoxia on catalase gene expression. Northern analysis showed that both BET-1A and HS-24 cells expressed the catalase gene, with the expected 2.4-kb catalase mRNA transcripts detectable in both cell types (Fig. 1). It was apparent from the autoradiograms that catalase mRNA transcripts decreased after exposure to $85 \% \mathrm{O}_{2}$ for $48 \mathrm{~h}$, whereas HSP-70 mRNA transcripts, used as a positive control to oxidant stress, markedly increased in both cell types. The ribosomal 18S RNA levels appeared constant in both cell types in response to hyperoxia.

Quantification of catalase and HSP-70 mRNA levels expressed as a ratio to the RNR-18S level, verified that there was 


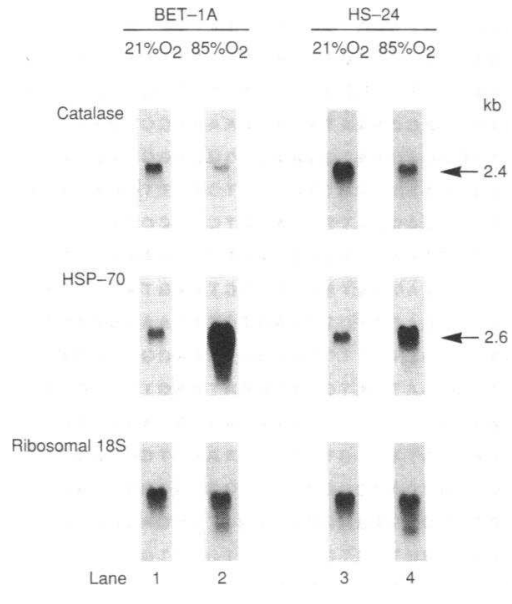

Figure 1. Effect of hyperoxia on expression of catalase mRNA in BET-1A and HS-24 human bronchial epithelial cells. Catalase mRNA was evaluated by Northern analysis of total RNA ( $10 \mu \mathrm{g}$ / lane) extracted from cells incubated in normoxia $\left(21 \% \mathrm{O}_{2}\right)$ and hyperoxia $\left(85 \% \mathrm{O}_{2}\right)$. Lane 1, BET-1A, 21\% $\mathrm{O}_{2}$; lane 2, BET-1A, $85 \% \mathrm{O}_{2}$; lane 3, HS-24, $21 \% \mathrm{O}_{2}$; lane 4 , HS-24, $85 \% \mathrm{O}_{2}$. Ribosomal $18 \mathrm{~S}$

RNA and HSP-70 mRNA transcripts are shown as negative and positive controls, respectively. The size of the mRNA transcripts are indicated.

a decline in the catalase mRNA levels with hyperoxia compared to normoxia, for both BET-1A and HS-24 cells ( $P$ $<0.001$ ) (all data are presented as mean \pm SE of the mean; all comparisons are made using the two-tailed Student's $t$ test) (Fig. 2). In marked contrast to the decline in catalase mRNA levels, the HSP-70 mRNA levels increased dramatically in response to hyperoxia, in HS-24 cells increasing by $208 \%$ ( $P$ $<0.02)$ and in BET-1A cells by $894 \%(P<0.0001)$ for both cell types compared to normoxia. Consistent with this decrease of catalase mRNA levels in response to hyperoxia, the catalase activity in the HS-24 cells decreased $(P<0.001)$ and did not change in the BET-1A cells $(P>0.1)$ (Fig. 2$)$.

Sequence analysis of 5'-flanking region of the human catalase gene. Sequence analysis of $1.7 \mathrm{~kb}$ of the region 5 '-flanking to exon 1 of the human catalase gene demonstrated structural features typical of a housekeeping gene (29). There was no TATA promoter element within $500 \mathrm{bp}$ upstream of the translation start codon, but there were five CCAAT boxes $(-1,207$, $-802,-297,-194$, and -165$)$, two inverted CCAAT box motifs ( -203 and -115$)$, and two Sp1 binding sites (Fig. 3). The GC content in the 5'-flanking region of the catalase gene was high, representing $67 \%$ of all bases for the sequence within the $400 \mathrm{bp}$ upstream from exon 1. Transcriptional factor search showed that there were no xenobiotic responsive elements (30) or antioxidant responsive elements (31) in the 5'-flanking region of the human catalase gene, but four regulatory elements of possible relevance to catalase gene expression were found. First, the c-myc protein binding consensus sequence that has been demonstrated to have enhancer activity (TCTCTTA, $-1,675$ to $-1,669$ ) (32). Second, a Pu box (GAGGAA, -708 to -703 ), an element activated by the oncogene-like protein Pu. 1 expressed in macrophages and B cell lines (33). Third, the sequence INF.1 (AAGTGA, -629 to -624 ), which is an element able to upregulate $\beta$-interferon gene expression in response to viral infection, although tandem repeats of this basic element are probably required (34). Finally, in the 5' untranslated region a glucocorticoid response element (TGTTCT, -25 to -20 ) is present, which could possibly confer inducibility of catalase gene expression in response to steroids as has been demonstrated in animal studies $(35,36)$.

Also consistent with the housekeeping nature of the human catalase 5'-flanking sequence (29), primer extension analysis showed multiple transcription start sites in both BET-1A and HS- 24 cells $(-235,-167,-142,-115,-100,-80,-73,-68$, and -61 ) with two major transcription start sites at -167 and -73 bp upstream from the translation start codon in exon 1 (Fig. 4). Primer extension analysis with a second primer CAT24 and S1 nuclease mapping showed the same results (not shown).

A homology search comparing the 1.7 -kb 5 '-flanking and exon 1 sequences of the human catalase gene and $4.8 \mathrm{~kb}$ of the 5 -flanking and exon 1 of the rat catalase gene showed $49.1 \%$ identity in a 1,628-bp overlapping region.

Promoter activity of 5'-flanking region of the catalase gene. Transfection studies of the HS-24 cells using fusion genes of 5 '-flanking sequences of the catalase gene and a luciferase reporter gene showed that these 5 '-flanking sequences had only low level promoter activity, representing $<3 \%$ of Rous sarcoma virus promoter activity for sequences from -84 to $-1,579$ (Fig. $5 A$ ). In this regard, sequence containing 242 bp immediately $5^{\prime}$ of the translation start codon had $71 \%$ of the highest activity of all constructs. There were only small increments with additional 5 ' sequence up to $-1,579 \mathrm{bp}$ from translation start codon.

After exposure to $85 \% \mathrm{O}_{2}$ for $24 \mathrm{~h}$, relative levels of reporter gene expression in transfected HS-24 cells were slightly decreased (Fig. $5 \mathrm{~B}$ ). Further, the pattern of activity of the various 5 '-flanking sequences was not changed compared to their activity in cells exposed to normoxia.

Protection of HS-24 cells by AdCL. Catalase activity in uninfected and AdCFTR-infected HS-24 cells were similar ( $P$ $>0.1$ ) (Fig. $6 \mathrm{~A}$ ). In contrast, the catalase activity in AdCL-infected cells was increased markedly, with values 20 -fold greater than both controls $(P<0.001)$.

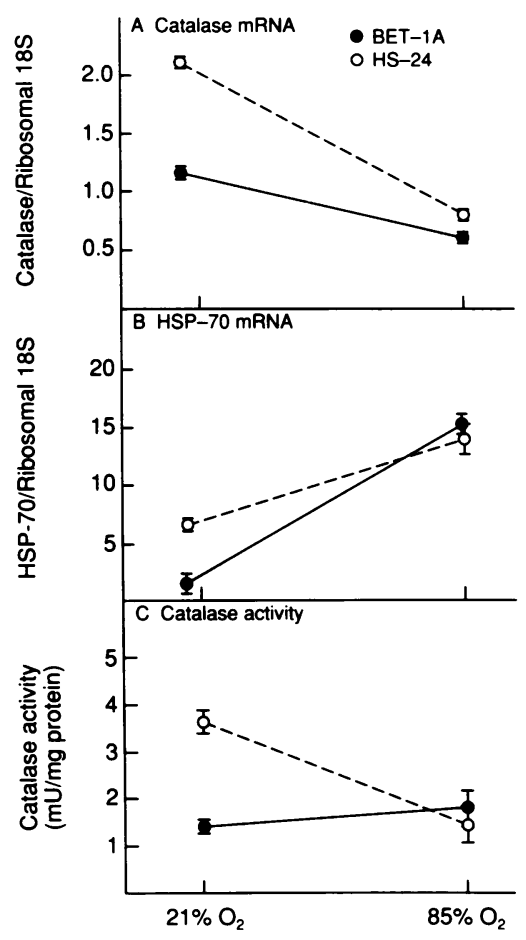

Figure 2. Effect of hyperoxia on catalase mRNA expression and catalase activity in human bronchial epithelial cell lines. Catalase mRNA expression and catalase activity were quantified in BET-1A cells incubated in $21 \%$ $(n=5)$ and $85 \% \mathrm{O}_{2}(n$ $=5)$, and in HS-24 cells in $21 \%(n=3)$ and $85 \%$ $(n=3) \mathrm{O}_{2}$ for $48 \mathrm{~h}$ after the cells reached confluence. $(A)$ Catalase mRNA expression shown as a ratio to control ribosomal $18 \mathrm{~S}$ expression. ( $B$ ) HSP-70 mRNA expression shown as a ratio to control ribosomal $18 \mathrm{~S}$ expression. In $A$ and $B$, the mRNA levels were quantified from Northern blots using a phosphorimager. $(C)$ Catalase activity in the cell lysates is expressed as $\mathrm{mU} / \mathrm{mg}$ total cellular protein. 


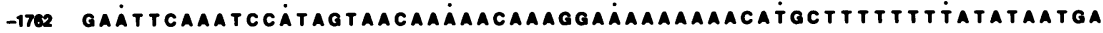

Figure 3. Nucleotide sequence of the 5 '-flanking region of the human catalase gene. Nucleotide position +1 is assigned to the A in ATG start codon and nucleotides $5^{\prime}$ of the start codon given negative numbers. Of the $3.1-\mathrm{kb}$ sequenced $5^{\prime}$ to intron 1 , the nucleotide sequence from $-1,762$ to +66 is shown; the entire sequence has been submitted to GenBank (accession number L13609). There are five CCAAT boxes ( $-1,207$, $-802,-297,-194$, and -165 , indicated as a box ) and two inverted CCAAT box motifs ( -203 and -115 , indicated as a wavy line). Two putative binding sites for the nuclear transcription factor Spl are indicated by the underlined GGGCGG core sequences at -382 and -139 .

Consistent with these observations, when uninfected, control AdCFTR-infected or AdCL-infected HS-24 cells were exposed to $95 \% \mathrm{O}_{2}$ for $3 \mathrm{~d}$ and their survival evaluated, it was clear that the relative proportion of viable cells after exposure to hyperoxia was increased in AdCL-infected cells (Fig. $6 \mathrm{~B}$ ). In this regard, the survival of the AdCL-infected cells was more than twofold greater than that of the uninfected cells $(P$ $<0.001)$ and threefold greater than that of the AdCFTR-infected cells $(P<0.001)$.

\section{Discussion}

Based on the knowledge that airway epithelial catalase mRNA levels are very low in normal humans, and that they do not increase with exposure to high concentrations of inhaled $\mathrm{O}_{2}$ (10), the present study evaluates one possible mechanism underlying the sensitivity of the airway epithelium to hyperoxia: that the expression of the catalase gene in human airway epithelium is not responsive to hyperoxia. The data show that human
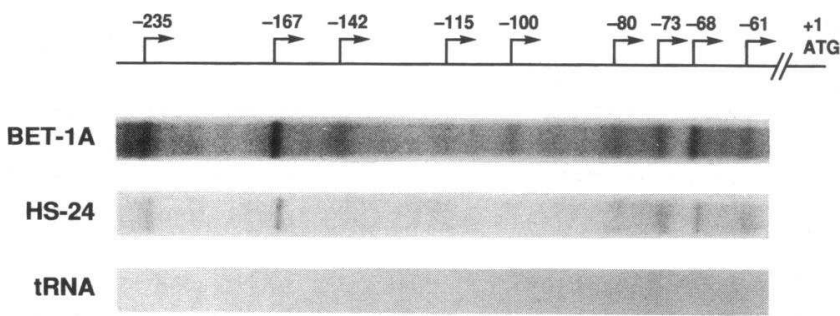

Figure 4. Identification of the transcription start sites of the human catalase gene. Shown is primer extension analysis of catalase mRNA from BET-1A and HS-24 cell lines using the antisense primer CAT-21 located at +55 to +32 , yeast transfer RNA is shown as a control. The results are shown diagramatically at the top along with representative autoradiograms. Multiple transcription start sites were observed between -235 and -61 in both BET-1A and HS-24 cells, with the two most prominent bands at -167 and -73 . catalase mRNA expression and intracellular catalase activity are not upregulated in response to hyperoxia in human bronchial epithelial cell lines in vitro. Consistent with this concept, analysis of the 5'-flanking region of the human catalase gene showed that: $(a)$ it has the characteristics of a "housekeeping" gene; $(b)$ it is transcribed at low levels; and $(c)$ it does not appear to have elements that upregulate the expression of the catalase gene in response to hyperoxia.

These observations in human airway epithelium differ from that observed in rodents. In this regard, rat lung catalase mRNA expression is upregulated by hyperoxia in vivo in neonatal rats (36) and by ozone in adult rats (37). Further, catalase mRNA levels are increased in hamster tracheal epithelial cells by exposure to $\mathrm{H}_{2} \mathrm{O}_{2}$ in vitro (38). These observations are of interest in that the rat catalase gene has a similar structure to the human catalase gene, including the 5'-flanking region with no TATA box, multiple CCAAT boxes, and GC-like boxes and multiple transcription start sites. In contrast to the human catalase gene, however, the rat catalase gene shows very strong promoter activity in vitro (39). While the mechanism underlying the differences in catalase gene expression between human and rodent airway epithelium are not clear, these observations highlight differences in rodents and humans in response and susceptibility to hyperoxia.

The fact that the human catalase gene is not upregulated in human airway epithelium in response to hyperoxia suggests that the sensitivity of this cell type to hyperoxia might be lessened if the catalase levels could be increased. The present study demonstrates the feasibility of this concept by capitalizing on the ability of replication deficient recombinant adenovirus vectors to infect and transfer exogenous genes to airway epithelial cells $(26,40,41)$. In this context, infection of human airway epithelial cells with AdCL (a replication-deficient Ad5-based virus containing the human catalase cDNA), conveyed to the airway epithelial cells increased levels of catalase activity and parallel protection against hyperoxia. These results confirm the efficacy of adenovirus mediated transfer of the human catalase cDNA to increase the antioxidant protection of a variety of 


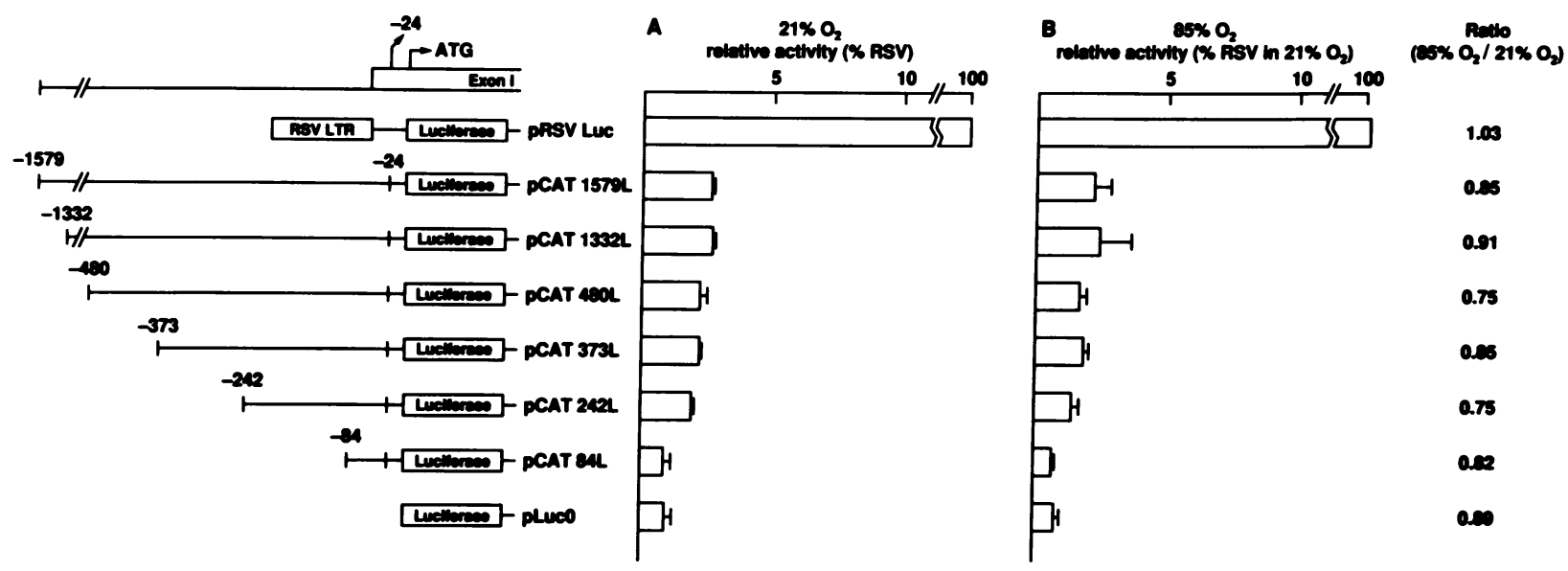

Figure 5. Promoter activity of the catalase gene 5'-flanking region. Levels of luciferase expression by fusion gene constructs of catalase 5'-flanking region and a luciferase reporter gene are shown relative to the expression of the positive control pRSVLuc. A promoterless luciferase plasmid served as a negative control. Each data point is the average of three independent transfection experiments. These promoter function analyses were carried out with HS-24 cells incubated in $(A) 21 \% \mathrm{O}_{2}$ and $(B) 85 \% \mathrm{O}_{2}$. At the right is shown the ratio of the promoter activity in $85 \% \mathrm{O}_{2}$ compared to $21 \% \mathrm{O}_{2}$.

human cells (25). Together with the knowledge that hyperoxia does not enhance catalase gene expression in the human airway epithelium in vivo (10) and in vitro, these observations suggest
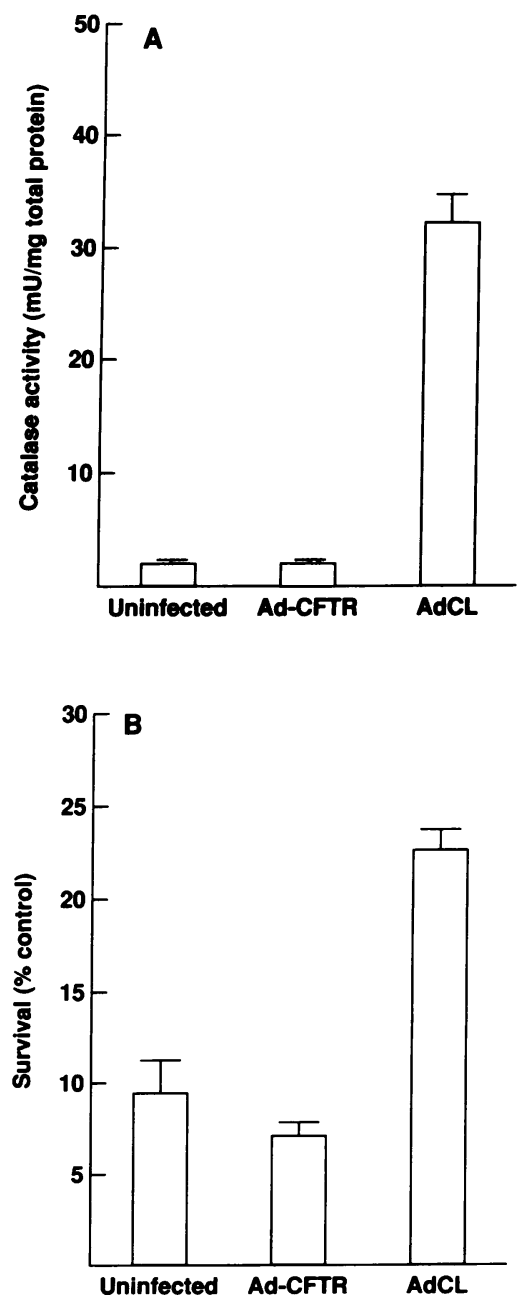
see Methods) in $95 \% \mathrm{O}_{2}$ for $72 \mathrm{~h}$ as a percentage of the number of viable cells in $21 \% \mathrm{O}_{2}$ for $72 \mathrm{~h}$.
Figure 6. Protection of HS-24 cells from hyperoxia by augmenting intracellular catalase levels by gene transfer. HS24 cells were infected with AdCL, a replication deficient adenovirus containing the human catalase cDNA. $(A)$ Catalase activity in the cells. Catalase activity in cell lysates was quantified spectrophotometrically and expressed as $\mathrm{mU} / \mathrm{mg}$ total protein. Shown is data from three separate experiments, for uninfected cells, cells infected with the control virus AdCFTR, and cells infected with AdCL. ( $B$ ) Quantification of the ability of AdCL to convey protection against hyperoxia in HS-24 cells. Shown is data from three separate experiments for uninfected cells, cells infected with the control virus AdCFTR, and cells infected with AdCL. The data is presented as the number of viable cells (as measured by the MTT as- it is rational to consider in vivo transfer of the catalase cDNA using an adenovirus vector for potential protection of the airway epithelium against hyperoxia in clinical circumstances requiring inhalation of high concentrations of oxygen for extended periods.

\section{References}

1. Halliwell, B., and J. M. C. Gutteridge. 1989. Oxygen is poisonous: an introduction to oxygen toxicity and free radicals. In Free Radicals in Biology and Medicine. Clarendon Press, Oxford. pp. 1-21.

2. Menzel, D. B. 1976. The role of free radicals in the toxicity of air pollutants (nitrogen oxide and ozone). In Free Radicals in Biology. W. A. Pryor, editor. Academic Press, New York. pp. 181-202.

3. Church, D. F., and W. A. Pryor. 1985. Free-radical chemistry of cigarette smoke and its toxicological implications. Environ. Health Perspect. 64:111-126.

4. Weiss, S. J., M. B. Lampert, and S. T. Test. 1983. Long-lived oxidants generated by human neutrophils: characterization and bioactivity. Science (Wash. DC). 222:625-628.

5. Heffner, J. E., and J. E. Repine. 1991. Antioxidants and the lung. In The Lung. R. G. Crystal and J. B. West, editors. Raven Press, Ltd., New York. pp. 1811-1820.

6. Heffner, J. E., and J. E. Repine. 1989. Pulmonary strategies of antioxidant defense. Am. Rev. Respir. Dis. 140:531-554.

7. Fridovich, I., and B. Freeman. 1986. Antioxidant defenses in the lung. Annu. Rev. Physiol. 48:693-702.

8. Deisseroth, A., and A. L. Dounce. 1970. Catalase: physical and chemical properties, mechanism of catalysis, and physiological role. Physiol. Rev. 50:319375.

9. Calabrese E. J., and A. T. Canada. 1989. Catalase: its role in xenobiotic detoxification. Pharmacol. \& Ther. 44:297-307.

10. Erzurum, S. C., C. Danel, A. Gillissen, C.-S. Chu, B. C. Trapnell, and R. G. Crystal. 1993. In vivo antioxidant gene expression in human airway epithelium of normal individuals exposed to $100 \%$ oxygen. J. Appl. Physiol. 75:12561262.

11. Reddel, R. R., Y. Ke, B. I. Gerwin, M. G. McMenamin, J. F. Lechner, R. T. Su, D. E. Brash, J.-B. Park, J. S. Rhim, and C. C. Harris. 1988. Transformation of human bronchial epithelial cells by infection with SV 40 or adenovirus-12 SV40 hybrid virus, or transfection via strontium phosphate coprecipitation with a plasmid containing SV40 early region genes. Cancer Res. 48:1904-1909.

12. Appelhan, B., B. Ender, G. Sachse, T. Nikiforov, H. Appelhans, and W. Ebert. 1987. Secretion of antileucoprotease from a human lung tumor cell line. FEBS (Fed. Eur. Biochem. Soc.) Lett. 224:14-18.

13. Chirgwin, J. M., A. E. Przybyla, R. J. MacDonald, and W. J. Rutter. 1979. Isolation of biologically active ribonucleic acid from sources enriched in ribonuclease. Biochemistry. 18:5294-5299.

14. Wu, B., C. Hunt, and R. Morimoto. 1985. Structure and expression of the human gene encoding major heat shock protein HSP70. Mol. Cell. Biol. 5:330341.

15. Donati, Y. R. A., D. O. Slosman, and B. S. Polla. 1990. Oxidative injury and the heat shock response. Biochem. Pharmacol. 40:2571-2577. 
16. Aebi, H. 1984. Catalase in vitro. Methods Enzymol. 105:121-126.

17. Sanger, F., S. Nicklen, and A. R. Coulson. 1977. DNA sequencing with chain-terminating inhibitors. Proc. Natl. Acad. Sci. USA. 74:5463-5467.

18. Ghosh, D. 1992. TFD: the transcription factors database. Nucleic Acids Res. 20:2091-2093.

19. Devereux, J., P. Haeberli, and O. Smithies. 1984. A comprehensive set of sequence analysis programs for the VAX. Nucleic Acids Res. 12:387-395.

20. Calzone, F. J., R. J. Britten, and E. H. Davidson. 1987. Mapping of gene transcripts by nuclease protection assays and cDNA primer extension. Methods Enzymol. 152:611-632.

21. Sambrook, J., E. T. Fritsch, and T. Maniatis. 1989. Mapping of RNA with nuclease S1 and single-stranded DNA probes. In Molecular Cloning: A Laboratory Manual. Cold Spring Harbor Laboratory Press, Plainview, NY. pp. 766-770.

22. Liu, J. M., H. Fujii, S. W. Green, N. Komatsu, N. S. Young, and T. Shimada. 1991. Indiscriminate activity from the B19 parvovirus P6 promoter in nonpermissive cells. Virology. 182:361-364.

23. De Wet, J. R., K. V. Wood, M. DeLuca, D. R. Helinski, and S. Subramani. 1987. Firefly luciferase gene: structure and expression in mammalian cells. Mol. Cell. Biol. 7:725-737.

24. Neumann, J. R., C. A. Morency, and K. O. Russian. 1987. A novel rapid assay for chloramphenicol acetyltransferase gene expression. Biotechniques. 5:444-447.

25. Erzurum, S. C., P. Lemarchand, M. A. Rosenfeld, J.-H. Yoo, and R. G. Crystal. 1993. Protection of human endothelial cells from oxidant injury by adenovirus-mediated transfer of the human catalase cDNA. Nucleic Acids Res. 21:1607-1612.

26. Rosenfeld, M. A., B. C. Trapnell, K. Yoneyama, E. R. Rosenthal, W. Dalemans, M. Fukayama, J. Bargon, L. E. Stier, L. Stratford-Perricaudet, M. Perricaudet, et al. 1992. In vivo transfer of the human cystic fibrosis transmembrane conductance regulator gene to the airway epithelium. Cell. 68:143-155.

27. Lemarchand, P., H. A. Jaffe, C. Danel, M. C. Cid, H. K. Kleinman, L. D. Stratford-Perricaudet, M. Perricaudet, A. Pavirani, J.-P. Lecocq, and R. G. Crystal. 1992. Adenovirus-mediated transfer of a recombinant human $\alpha_{1}$-antitrypsin cDNA to human endothelial cells. Proc. Natl. Acad. Sci. USA. 89:6482-6486.

28. Mosmann, T. 1983. Rapid colorimetric assay for cellular growth and survival: application to proliferation and cytotoxicity assays. J. Immunol. Methods. 65:55-63.
29. Dynan, W. S. 1986. Promoters for housekeeping genes. Trends Genet. 2:196-197.

30. Rushmore, T. H., and C. B. Pickett. 1990. Transcriptional regulation of the rat glutathione S-transferase Ya subunit gene. J. Biol. Chem. 265:1464814653.

31. Rushmore, T. H., M. R. Morton, and C. B. Pickett. 1991. The antioxidant responsive element. J. Biol. Chem. 266:11632-11639.

32. Ariga, H., Y. Imamura, and S. M. M. Iguchi-Ariga. 1989. DNA replication origin and transcriptional enhancer in c-myc gene share the c-myc protein binding sequences. EMBO (Eur. Mol. Biol. Organ.) J. 8:4273-4279.

33. Klemsz, M. J., S. R. McKercher, A. Celada, C. Van Beveren, and R. A. Maki. 1990. The macrophage and B cell-specific transcription factor PU.1 is related to the ets oncogene. Cell. 61:113-124.

34. Fujita, T., H. Shibuya, H. Hotta, K. Yamanishi, and T. Taniguchi. 1987. Inteferon- $\beta$ gene regulation: tandemly repeated sequences of a synthetic $6 \mathrm{bp}$ oligomer function as a virus-inducible enhancer. Cell. 49:357-367.

35. Scheidereit, C., S. Geisse, H. M. Westphal, and M. Beato. 1983. The glucocorticoid receptor binds to defined nucleotide sequences near the promoter of mouse mammary tumour virus. Nature (Lond.). 304:749-752.

36. Clerch, L. B., J. Iqbal, and D. Massaro. 1991. Perinatal rat lung catalase gene expression: influence of corticosteroid and hyperoxia. Am. J. Physiol. 260:L428-L433.

37. Rahman, I.-U., L. B. Clerch, and D. Massaro. 1991. Rat lung antioxidant enzyme induction by ozone. Am. J. Physiol. 260:L412-L418.

38. Shull, S., N. H. Heintz, M. Periasamy, M. Manohar, Y. M. W. Janssen, J. P. Marsh, and B. T. Mossman. 1991. Differential regulation of antioxidant enzymes in response to oxidants. J. Biol. Chem. 266:24398-24403.

39. Sato, K., K. Ito, H. Kohara, Y. Yamaguchi, K. Adachi, and H. Endo. 1992. Negative regulation of catalase gene expression in hepatoma cells. Mol. Cell. Biol. 12:2525-2533.

40. Rosenfeld, M. A., W. Siegfried, K. Yoshimura, K. Yoneyama, M. Fukayama, L. E. Stier, P. K. Pääkkö, P. Gilardi, L. D. Stratford-Perricaudet, M. Perricaudet, et al. 1991. Adenovirus-mediated transfer of a recombinant $\alpha 1$-antitrypsin gene to the lung epithelium in vivo. Science (Wash. DC). 252:431-434.

41. Mastrangeli, A., C. Danel, M. A. Rosenfeld, L. Stratford-Perricaudet, M. Perricaudet, A. Pavirani, J.-P. Lecocq, and R. G. Crystal. 1993. Diversity of airway epithelial cell targets for in vivo recombinant adenovirus mediated gene transfer. J. Clin. Invest. 91:225-234. 